give a larger output per acre than other kinds of produce.

Account must also be taken of the part that agriculture can play in solving social problems such as unemployment and the rehabilitation of the unfit, and also of the vitally important problem of safety in war-time.

Seience must always play an important part in agricultural development, though it needs careful management because of the wide difference in outlook between scientific workers and agriculturists. Agricultural operations are so dominated by weather and by other disturbing factors, including pests and diseases, that no rigid rules can be laid down. An experimental result can never have quite the same validity as in a chemical or physical laboratory. It may always be profoundly affected by some wholly unexpected and perhaps unobserved factor, and until it has been confirmed over a wide range of conditions it is liable to the suspicion that it may be abnormal. When all results are assembled they can be subjected to statistical analysis and an average obtained with its appropriate standard error, but it may not apply. on any particular farm even though over a hundred farms it might hold good for a majority. Frequently the farmer has arrived at a general fund of knowledge about his own farm, which he is reluctant to disturb except on very convincing evidence. 'Good husbandry' is his ideal, and he firmly believes in its 'rules', even though some of them very inadequately express the facts. The agricultural departments of the colleges necessarily reflect this attitude: farmers and students alike are usually more interested in practice than in science and so more influenced by experience than by experiments : indeed not infrequently they are prepared to ignore or at least heavily discount experimental evidence if it does not fit in with established ideas. Their outlook on Nature is usually vitalistic, and special virtue is always supposed to reside in anything of organic origin as against substances of mineral or synthetic origin.

So a difference in outlook tends to arise between the agricultural research institutes and the agricultural community they are hoping to serve, and the difierence is widened by the circumstance that the research institutes, if they are to keep their science at a serious level, have almost always to draw their staff from the science departments of the universities; usually the candidate who is otherwise most suitable has no rural background and no knowledge of agriculture; to acquire this is generally very difficult. It is necessary also to distinguish between the good research man and the good adviser, and to determine the place the adviser should have in the research institute.
Broadly speaking, the good research man can see his problem, study it in full detail and find a solution, going on with the work until he has rounded it off properly and written it up for publication. But often it is not immediately useful for practical farming, though, of course, new knowledge is bound to find its place in agricultural seience and practice. The good advisory officer can also see his problem and study it in detail; he, too, finds a solution, which may be of more immediate service on the farm than the scientific investigation. But he rarely goes beyond the stage of the interim report, so that his work is never rounded off and much of it never published, to the loss of public funds and the detriment of the juniors who also participated.

In the days when they were small, the research institutes necessarily kept close touch with the farming community and had to do both types of work: the individual members of the sta 9 knew many farmers personally and well. As agricultural science has developed and expanded, it is the advisory officer rather than the research man that has had most to do with practical farming problems. This is in part the explanation of the curious decrying of science by some agricultural writers and the elevation into prominence of some of the mystical hypotheses of plant growth and human and animal nutrition which cannot be tested scientifically. These serious problems in the relation of science to agriculture require fuller study.

\section{SCIENTIFIC CENTENARIES IN 1942}

\section{BY ENGINEER CAPTAIN EDGAR C. SMITH, O.B.E., R.N.}

GCATTERED through the coming year are days $S$ which will mark the centenaries of some of the most famous men of all time. In happier circumstances, it may be presumed that already arrangements would be in progress for the commemoration of some of these centenaries on an international scale. But more urgent tasks lie ahead. Yet it may, perhaps, be hoped that such events as the tercentenary of the death of Galileo, the tercentenary of the birth of Newton and the bicentenary of Halley will not be allowed to pass quite unnoticed. It is unnecessary to recall how the researches and discoveries of these great pioneers are closely interwoven, but it may, perhaps, be permitted to recall Rigaud's words regarding the publication of Newton's "Principia". In his essay on that immortal work Rigaud wrote: "Under the circumstances it is hardly possible to form a sufficient estimate of the immense obligation which the world owes in this respect to Halley, 
without whose great zeal, able management, unwearied perseverance, scientific attainments and disinterested generosity the Principia might never have been published."

When Halley died he had held the office of Astronomer Royal for some twenty years, having succeeded Flamsteed in 1720. His death took place on January 14,1742, a few months before that of Abraham Sharp, who had furnished Flamsteed with instruments, and of whom Smeaton, in a report in the Philosophical Transactions in 1786, said that "I look upon Mr. Sharp as having been the first person that cut accurate and delicate divisions upon astronomical instruments".

Another interesting figure of those times, and one well known in Great Britain, was the Dutch mathematician Wilhelm Jacob 's Gravesande (16881742), the first professor of the University of Leyden to teach the Newtonian philosophy, and the author of a work on natural philosophy, Desagulier's translation of which was studied eagerly by James Watt as a boy of fifteen.

The men of science born in 1742 include the famous Swedish chemist Scheele, the German natural philosopher Lichtenberg and the unfortunate French chemist and inventor Nicolas Leblanc. When surgeon to the Duke of Orleans, Leblanc, to gain a prize offered by the Paris Academy of Sciences, set himself the problem of making soda from common salt. After several years he was rewarded with success, and with the aid of the Duke a factory was erected at St. Denis. Then came the French Revolution. The Duke was guillotined, the factory was confiscated and Leblanc forced to reveal his process. After much misery Leblanc, in 1806, died by his own hand. At one time his name was almost forgotten, but to-day his statue stands in the forecourt of the Conservatoire des Arts et Métiers in Paris.

Coming down to 1842 the list lengthens, but it is proposed to refer to only a few of the more important men. In April of that year the British surgeon, Sir Charles Bell, died suddenly at the age of sixty-eight; on September 6 the Belgian chemist Jean Baptiste van Mons passed away at Louvain, having done much to spread a knowledge of the discoveries of Lavoisier and his successors, and on September 21 the British mathematician Sir James Ivory, Copley medallist in 1814, died in Hampstead. The month of February 1842 saw the birth of the French astronomer Camille Flammarion (died, 1925), the month of April the birth of the German astronomer Hermann Carl Vogel (died, 1907). Carl von Linde, the German pioneer of refrigeration, was born in June 1842 ; the German chemist Albert Ladenburg, in

July. Sir William Tilden, Sir James Dewar and Lord Rayleigh were all born in the latter part of
1842, as were also the Norwegian mathematician Marius Sophia Lie, For. Mem. R.S., and the Russian chemist, Nicolai Alexandrovich Menschutkin, one of the outstanding contemporaries of Mendeléeff. Lie died in 1899, Menschutkin in 1907. A memoir of the latter by Tilden appeared in the Journal of the Chemical Society in 1911.

\section{OBITUARIES}

\section{Prof. Rudolf Schoenheimer}

$\mathrm{T}$ HE death of Rudolf Schoenheimer at the early age of forty-three has removed from our midst a biochemist of outstanding ability. His work, characterized always by originality of conception, has opened up a new, and most fertile, field in biochemistry.

Schoenheimer was born in Berlin in 1898 and he received his M.D. there in 1922 . He was associated with the University of Freiburg and became head of its Department of Pathological Chemistry in 1931. He left Germany in 1933 to take up a position as assistant, and later as associate, professor of biochemistry in the College of Physicians and Surgeons, Columbia University. He held this position at the time of his death in September 1941.

Schoenheimer's work, until he went finally to the United States, was concerned primarily with the metabolism of cholesterol. He continued his studies on cholesterol for a few years and in 1934 he commenced his work on the application of stable isotopes to the study of intermediary metabolism. During the following seven years Schoenheimer, usually in co-operation with his colleague D. Rittenberg, developed this new experimental approach to problems of biochemistry.

Much of our knowledge of intermediary metabolism depends on an analysis of the products formed after the administration to an animal of substances which may or may not be normal metabolites. The method has been extended to the use of intact isolated organs (by perfusion techniques) or of surviving tissue slices. Much valuable information has been and is still being obtained by work carried out in this manner. It is recognized, however, that this method of investigation has definite limitations. Administration to the body of relatively large quantities of even normal metabolites may upset the normal balance of events and call forth changes which do not reflect the normal quantitative relation. ships. Administration of substances, labelled with halogen, phenyl or other groups to facilitate the chemical examination of intermediates in the process of breakdown of the parent substances, involves the use of compounds having different chemical and physical properties from those of normal substrates and metabolites. Such substances, foreign to the body, may be treated, in certain respects, differently from normal substances. Yet the elucidation of the intermediate steps in the course of breakdown of 